\title{
PENGARUH PEMOTONGAN UMBI TERHADAP PERTUMBUHAN DAN HASIL TANAMAN TIGA VARIETAS BAWANG MERAH (Allium ascalonicum L.) PADA TANAH SPODOSOL \\ ( Effect of Buld Cutting on Growth and Yields of Three Varieties of Red Onions (Allium ascalonicum L) on Spodosol )
}

\author{
Haloho, G., H. ${ }^{\text {) }}$, Syahrudin ${ }^{1)}$, Suparto, H. ${ }^{1}$ \\ 1) Jurusan Budidaya Pertanian Fakultas Pertanian Universitas Palangka Raya \\ Jl. Yos Sudarso Komplek Tunjung Nyaho Palangka Raya 73111 Kalimantan Tengah \\ Telp : 081349752578 e-mail : syahrudin 03@yahoo.co.id \\ Disterima : $18 / 12 / 2018 \quad$ Disetujui : $13 / 03 / 2019$
}

\begin{abstract}
ABSTRAK
Penelitian ini bertujuan untuk mengetahui pengaruh pemotongan umbi terhadap pertumbuhan dan hasil tanaman tiga varietas bawang merah pada tanah spodosol. Rancangan yang digunakan dalam percobaan ini adalah Rancangan Acak Kelompok (RAK) Faktorial yang terdiri dari 2 faktor perlakuan. Faktor pertama adalah pemotongan umbi bibit bawang merah,yaitu : $\mathrm{P}_{0}=$ tanpa pemotongan, $\mathrm{P}_{1}=$ pemotongan setengah $(1 / 2), \mathrm{P}_{2}=$ pemotongan sepertiga $(1 / 3) \mathrm{P}_{3}=$ pemotongan seperempat (1/4). Faktor kedua adalah varietas bawang merah, yang terdiri 3 varietas, yaitu : $V_{1}=$ varietas $B a u j i, V_{2}=$ varietas Bima Brebes dan $V_{3}=$ varietas Tajuk. Hasil penelitian menunjukkan bahwa interaksi pemotongan umbi dan varietas bawang merah berpengaruh terhadap jumlah daun dan bobot brangkasan segar. Kombinasi perlakuan pemotongan umbi 1/3 dan penggunaan varietas Tajuk mampu meningkatkan jumlah daun dan bobot brangkasan segar. Hasil bawang merah terbaik terdapat pada perlakuan pemotongan umbi 1/3 (sepertiga) dan varietas Tajuk dengan perolehan hasil bobot brangkasan segar $1126,67 \mathrm{~g} /$ petak atau setara dengan 23,47 ton.ha $^{-1}$.
\end{abstract}

Kata kunci : pemotong umbi, bawang merah, varietas, spodosol.

\begin{abstract}
The purposed of this experiment the effect of bulbs cutting on growth and yield of three varieties of onion on spodosol. This study used Randomized Block Design (RBD) of factorial pattern with two factors : The first factor was cutting the tuber ofonion of 4 levels, namely : P0 = no cutting, P1 = cutting $1 / 2, \mathrm{P} 2=$ cutting $1 / 3$, and $\mathrm{P} 3=$ cutting $1 / 4$. The second factor was the red onion varieties, consisting of 3 varieties, namely: V1 = Varietas Bauji, V2 = Varieties Bima Brebes and V3 = Varieties Tajuk. The results showed that interaction of the part cuttings and varieties of onion bulbs have an effect on the number of leaves and weight of fresh palnt biomassa. Combination treatment of cutting 1/3 bulbs and Tajuk varieties could be able to inrease the number of leaves and weight of fresh plant biomassa. The best results of onion per harvest swaths of the best there is on the treatment of cutting the tuber $1 / 3$ and of the Tajuk varieties with the acquisition of weight fresh stover (1126.67 $\mathrm{g}) / \mathrm{plot}$ harvest or the equivalent of 23.47. ton.ha ${ }^{-1}$.
\end{abstract}

Keywords: cutting bulb, red onion, varieties, spodosol.

\section{PENDAHULUAN}

Tanaman bawang merah (Allium ascalonicum L.) diperkirakan berasal dari Asia Tengah, beberapa literatur menyebutkan berasal dari India dan Pakistan hingga Palestina.
Tanaman ini tersebar mulai dari Eropa ke berbagai negara, termasuk daerah ekoator. Di Indonesia, bawang merah dibudidayakan oleh petani di daerah dataran rendah hingga dataran tinggi (Pitojo, 2003). 
Di Indonesia produksi bawang merah pada tahun 2015 mencapai 1.229.189 ton diikuti pada tahun 2016 sebanyak 1.446 .869 ton. Produksi bawang merah di Kalimantan Tengah pada tahun 2016 mencapai 200 ton, sedangkan di Palangka Raya produksi bawang merah pada tahun 2016 sebanyak 31,9 ton (BPS, 2017). Dari data tersebut diketahui bahwa produksi bawang merah di Palangka Raya cukup rendah, sehingga perlu dilakukan penelitian.

Penanaman dari beberapa varietas untuk hasil bawang merah di Kalimatan Tengah terus ditingkatkan, agar memenuhi kebutuhan masyarakat. Beberapa hasil penelitian menunjukkan bahwa salah satu perbaikan teknologi budidaya untuk peningkatan produktivitas bawang merah ialah melalui penggunaan bibit unggul.. Pada pertengahan tahun 2013 pengembangan lebih lanjut dilakukan menggunakan varietas Super Philips. Hasil panen terbaik mampu dicapai beberapa petani hingga 12,4 ton.ha ${ }^{-1}$ umbi bawang merah kering di lahan pasir kuarsa (Firmansyah, 2014). Kemudian dilanjutkan dari hasil penelitian Firmansyah (2014) telah menghasilkan varietas unggul bawang merah yang dapat dibudidayakan di luar musim atau pada musim hujan (off-season), yaitu salah satunya varietas Bima Brebes dengan hasil panen 7,20 ton.ha ${ }^{-1}$.

Selama ini para petani selain menggunakan bibit dari berbagai ukuran juga bibit yang mereka tanam berasal dari umbi komsumsi. Kemudian serta kesehatannya sangat diragukan karena adanya kontaminasi dari generasi sebelumnya tidak terdeteksi sehingga produksi yang diperoleh menjadi rendah. Keberhasilan usaha tani ditentukan oleh penggunaan bibit dengan mutu baik dan teknik penanaman yang tepat. Untuk mengatasi masalah tersebut perlu pengadaan bibit bermutu, mengetahui berapa ukuran bibit yang paling optimal. Seleksi umbi bibit merupakan langkah awal yang sangat menentukan keberhasilan produksi. Menurut Wibowo (2005), pemotongan ujung umbi bibit dengan pisau bersih kira kira $1 / 3$ atau $1 / 4$ bagian dari panjang umbi, yang bertujuan agar umbi tumbuh merata, dapat merangsang tunas, mempercepat tumbuhnya tanaman, dapat merangsang tumbuhnya umbi samping dan dapat mendorong terbentuknya anakan. Selanjutnya Samadi dan Cahyono (2005) menambahkan sebelum ditanam umbi bibit bawang merah pada bagian ujung umbi dipotong sebesar $1 / 4$ sampai $1 / 3$ bagian, sesuai dengan kondisi bibit.. Kelemahannya jika umbi bibit tidak dipotong ujungnya, maka pertumbuhan dan produksi tanaman terhambat serta hasil umbinya menurun. Akan tetapi hatihati dalam memotongnya, jangan sampai tunas yang ada dalam umbi ikut terpotong (Rahayu, 2004).

Berdasarkan uraian di atas perlu dilakukan suatu penelitian tentang pengaruh pemotongan umbi terhadap pertumbuhan dan hasil tiga varietas bawang merah pada tanah spodosol.

\section{BAHAN DAN METODE}

Penelitian dilaksanakan pada bulan Maret sampai Mei 2018, bertempat di Jl. Pantung, Kelurahan Banturung, Kecamatan Bukit Batu, Kota Palangka Raya.

Bahan-bahan yang digunakan dalam penelitian ini adalah benih bawang merah varietas Bauji, Bima Brebes, Tajuk, pupuk majemuk NPK Permata Negeri (16-16-16), SP36, dolomit $\left(\mathrm{CaMg}\left(\mathrm{CO}_{3}\right)_{2}\right)$, pupuk kandang dan tali plastik. Alat-alat yang digunakan adalah parang, cangkul, garu sisir tanah, gembor, meteran, timbangan analitik, penggaris, alat tulis, kamera, dan peralatan penunjang lainnya.

Penelitian menggunakan Rancangan Acak Kelompok (RAK) Faktorial terdiri dari 2 faktor. Faktor pertama adalah pemotongan umbi bibit bawang merah terdiri dari 4 (empat) cara pemotongan yaitu : $\mathrm{P}_{0}=$ Tanpa pemotongan umbi , $\mathrm{P}_{1}=$ dipotong $1 / 2$ bagian ujung umbi, $\mathrm{P}_{2}$ $=$ dipotong $1 / 3$ bagian ujung umbi , $\mathrm{P}_{3}=$ dipotong $1 / 4$ bagian ujung umbi bibit bawang merah. Faktor kedua adalah varietas bawang merah $(\mathrm{V})$ yang terdiri dari 3 (tiga) varietas yaitu : $\mathrm{V}_{1}=$ Varietas Bauji, $\mathrm{V}_{2}=$ Varietas Bima Brebes_dan $\mathrm{V}_{3}=$ Varietas Tajuk. Masingmasing kombinasi perlakuan diulang tiga kali sehingga terdapat 36 satuan percobaan.

Petakan yang digunakan berukuran berukuran $180 \times 135 \mathrm{~cm}$ dengan jarak tanam 20 $\mathrm{x} 15 \mathrm{~cm}$. Variabel yang diamati dalam penelitian ini adalah : jumlah daun, jumlah 
anakan, jumlah umbi per tanaman, bobot berangkasan segar dan kering.

\section{HASIL DAN PEMBAHASAN}

\section{Jumlah Daun}

Hasil analisi ragam menunjukkan bahwa interaksi pemotongan umbi bibit pada tiga varietas bawang merah terhadap jumlah daun berpengaruh nyata pada umur 35, 42, 49 dan 56 hari. Penggunaan varietas bepengaruh nyata pada umur pengamatan 14, 21 dan 28 hari, sedangkan pemotongan umbi bibit berpengaruh nyata pada 14 hari setelah tanam. Rata-rata jumlah daun bawang merah akibat pemotongan umbi dan penggunaan tiga varietas disajikan pada Tabel 1 .

Berdasarkan Tabel 1 pemotongan umbi bibit berpengaruh dalam meningkatkan jumlah daun pada umur 14 hari setelah tanam, sedangkan penggunaan varietas berpengaruh nyata pada pengamatan 14, 21 dan hst, dimana jumlah daun terbanyak terdapat pada varietas Tajuk. Selanjutnya kombinasi perlakuan pemotongan umbi $1 / 4$ dan penggunaan varietas Tajuk pada pengamatan 35, 42, 49 dan 56 hst mampu dalam meningkatkan jumlah daun bawang merah. Pemotongan umbi bibit akan mempercepat daya tumbuh tanaman dan jumlah daun karena tujuan pemotongan ujung umbi bibit ini adalah agar umbi dapat tumbuh merata, untuk merangsang tumbuhnya tunas, mempercepat tumbuhnya tanaman, dan merangsang tumbuhnya anakan, sebagaimana yang diungkapkan oleh Rukmana (1995) , sebelum umbi bibit bawang merah ditanam, sebaiknya dilakukan pemotongan ujung umbi bibit.

Tabel 1. Rata-rata jumlah daun akibat pemotongan umbi bibit pada tiga varietas bawang merah pada umur 14, 21, 28, 35, 42, 49 dan 56 hari setelah tanam

\begin{tabular}{|c|c|c|c|c|c|c|}
\hline \multirow{2}{*}{ Umur } & \multirow{2}{*}{$\begin{array}{c}\text { Varietas } \\
\text { (V) }\end{array}$} & \multicolumn{4}{|c|}{ Pemotongan Umbi (P) } & \multirow{2}{*}{ Rata-rata } \\
\hline & & P0 & P1 & P2 & P3 & \\
\hline \multirow{3}{*}{$14 \mathrm{hst}$} & V1 & 11.16 & 13.00 & 11.11 & 11.94 & $11.80 \mathrm{~b}$ \\
\hline & $\mathrm{V} 2$ & 7.39 & 11.72 & 9.56 & 9.67 & $9.58 \mathrm{a}$ \\
\hline & V3 & 14.11 & 16.72 & 16.56 & 15.17 & $15.64 \mathrm{c}$ \\
\hline \multicolumn{2}{|c|}{ Rata-rata } & $10.89 \mathrm{a}$ & $13.81 \mathrm{~b}$ & $12.41 \mathrm{ab}$ & $12.26 \mathrm{ab}$ & \\
\hline \multirow{3}{*}{$21 \mathrm{hst}$} & V1 & 16.39 & 17.17 & 12.39 & 16.67 & $15.65 \mathrm{a}$ \\
\hline & $\mathrm{V} 2$ & 13.44 & 17.89 & 15.61 & 16.06 & $15.75 \mathrm{a}$ \\
\hline & V3 & 22.11 & 26.83 & 25.06 & 21.67 & $23.92 \mathrm{~b}$ \\
\hline \multicolumn{2}{|c|}{ Rata-rata } & 17.31 & 20.63 & 17.69 & 18.13 & \\
\hline \multirow{3}{*}{$28 \mathrm{hst}$} & V1 & 16.39 & 17.17 & 12.39 & 16.67 & $15.65 \mathrm{a}$ \\
\hline & $\mathrm{V} 2$ & 13.44 & 17.89 & 15.61 & 16.06 & $15.75 \mathrm{a}$ \\
\hline & $\mathrm{V} 3$ & 22.11 & 26.83 & 25.06 & 21.67 & $23.92 \mathrm{~b}$ \\
\hline \multicolumn{2}{|c|}{ Rata-rata } & 17.31 & 20.63 & 17.69 & 18.13 & \\
\hline \multirow{3}{*}{35 hst } & V1 & $23.56 \mathrm{ab}$ & $21.67 \mathrm{ab}$ & $16.56 \mathrm{a}$ & $22.78 \mathrm{ab}$ & 21.14 \\
\hline & V2 & $22.39 \mathrm{ab}$ & $27.28 \mathrm{bc}$ & $25.83 \mathrm{ab}$ & $24.78 \mathrm{ab}$ & 25.07 \\
\hline & $\mathrm{V} 3$ & $30.32 \mathrm{bcd}$ & $36.67 \mathrm{~cd}$ & $37.94 \mathrm{~d}$ & $30.33 \mathrm{bcd}$ & 33.82 \\
\hline \multicolumn{2}{|c|}{ Rata-rata } & 25.42 & 28.54 & 26.78 & 25.96 & \\
\hline \multirow{3}{*}{$42 \mathrm{hst}$} & V1 & 26.28 abcd & 24.28 abcd & $17.61 \mathrm{a}$ & 23.78 abc & 22.99 \\
\hline & $\mathrm{V} 2$ & $22.61 \mathrm{abcd}$ & $28.61 \mathrm{bcd}$ & $26.33 \mathrm{abcd}$ & $29.28 \mathrm{bcd}$ & 26.71 \\
\hline & V3 & $30.77 \mathrm{bcd}$ & $33.50 \mathrm{~cd}$ & $34.00 \mathrm{~d}$ & $26.22 \mathrm{abcd}$ & 31.12 \\
\hline \multicolumn{2}{|c|}{ Rata-rata } & 26.55 & 28.80 & 25.98 & 26.43 & \\
\hline \multirow{3}{*}{49 hst } & V1 & 26.28 abcd & 24.28 abcd & $17.61 \mathrm{a}$ & $23.78 \mathrm{abc}$ & 22.99 \\
\hline & V2 & $22.61 \mathrm{abcd}$ & $28.61 \mathrm{bcd}$ & $26.33 \mathrm{abcd}$ & $29.28 \mathrm{bcd}$ & 26.71 \\
\hline & $\mathrm{V} 3$ & 30.77 bcd & $33.50 \mathrm{~cd}$ & $34.00 \mathrm{~d}$ & $26.22 \mathrm{abcd}$ & 31.12 \\
\hline \multicolumn{2}{|c|}{ Rata-rata } & 26.55 & 28.80 & 25.98 & 26.43 & \\
\hline \multirow{3}{*}{$56 \mathrm{hst}$} & V1 & $24.83 \mathrm{abc}$ & $22.78 \mathrm{abc}$ & $16.78 \mathrm{a}$ & $22.44 \mathrm{abc}$ & 21.71 \\
\hline & $\mathrm{V} 2$ & $21.02 \mathrm{abc}$ & $26.83 \mathrm{abc}$ & $23.67 \mathrm{abc}$ & $27.22 \mathrm{bc}$ & 24.68 \\
\hline & V3 & $28.82 \mathrm{bc}$ & $31.11 \mathrm{c}$ & $31.28 \mathrm{c}$ & $24.39 \mathrm{abc}$ & 28.90 \\
\hline \multicolumn{2}{|c|}{ Rata-rata } & 24.89 & 26.91 & 23.91 & 24.69 & \\
\hline
\end{tabular}

Keterangan : Angka yang diikuti oleh huruf yang sama pada kolom, baris dan umur yang sama menunjukkan tidak berbeda nyata pada taraf Uji-BNJ $5 \%$. 
Pemotongan umbi bibit meregenerasi titik tumbuh tanaman sehingga memacu pertumbuhan tanaman dalam hal ini adalah jumlah daun. Jumlah daun tanaman merupakan komponen yang dapat menunjukkan pertumbuhan tanaman. Pembentukan daun sendiri sebetulnya dipengaruhi oleh sifat genetik tanaman, namun lingkungan yang baik dapat mempercepat pembentukkan tersebut. Jumlah daun tidak dipengaruhi oleh lingkungan tetapi jumlah daun dipengaruhi oleh sifat genetis tanaman hingga fase berbunga. (Putra et. al., 2012).

Varietas Tajuk secara umum memiliki daya tumbuh dan pertumbuhan yang tinggi dari pada varietas yang lain, hal ini disebabkan karena faktor genetik dari pada varietas itu sendiri, lingkungan tumbuh yang sesuai, dan keadaan fisik tanah yang cukup baik sehingga perlakuan varietas memberikan pengaruh jumlah jumlah daun terhadap tiga varietas bawang merah. Pembentukan daun juga dipengaruhi oleh proses pembelahan sel, perpanjangan sel, dan diferensiasi sel (Kimbal, 1990) . Semakin banyak jumlah anakan, maka jumlah daun yang dihasilkan juga semakin banyak (Putrasamedja,2010).

Menurut Gardner et. al. (1991), bahwa daya tumbuh dan pertumbuhan tanaman sangat dipengaruhi oleh faktor luar dan dalam. Faktor dalam salah satunya adalah sifat genetik dari varietas tersebut. Sedangkan faktor luar adalah iklim, suhu, kelembaban, curah hujan, ketersediaan hara dan intensitas sinar matahari.

\section{Jumlah Anakan}

Hasil analisis ragam interaksi pemotongan umbi bibit pada tiga varietas bawang merah terhadap jumlah anakan tidak berpengaruh nyata, demikian juga dengan faktor tunggal pemotongan umbi. Varietas berpengaruh nyata pada semua umur pengamatan. Rata-rata jumlah anakan akibat pemotongan umbi bibit dan tiga varietas bawang merah pada semua umur pengamatan dapat dilihat pada Tabel 2.

Dari Tabel 2 dapat dilihat bahwa penggunaan tiga varietas bawang merah berbeda nyata terhadap jumlah anakan, dimana pada umur 14 sampai 56 hari penggunaan varietas bawang merah $\mathrm{V}_{3}$ (Varietas Tajuk) memiliki jumlah anakan terbanyak dibandingkan varietas lainnya, hal ini disebabkan karena penggunaan varietas Tajuk mampu beradaptasi pada tanah spodosol. Menurut Simatupang (1997), meningkatnya produksi suatu varietas disebabkan varietas tersebut telah beradaptasi dengan lingkungan tumbuhnya, walaupun secara genotipe, varietas lain mempunyai potensi produksi dan mutu yang lebih baik. akan tetapi, karena masih dalam tahap beradaptasi maka produksinya lebih rendah daripada yang seharusnya.

Umur 42 hari setelah tanam tidak terjadi penambahan jumlah anakan dikarenakan tanaman memasuki fase generatif. Salisbury dan Ross (1995) menyatakan bahwa perkembangan fase reproduktif menyebabkan pengalihan hara menuju organ generatif, sehingga memperlambat pertumbuhan vegetatif dan mendorong fase akhir penuaan.

\section{Jumlah Umbi}

Hasil analisis ragam menunjukkan interaksi dan pemotongan umbi tidak berpengaruh nyata terhadap jumlah umbi, sedangkan varietas berpengaruh sangat nyata. Rata-rata jumlah umbi akibat pemotongan umbi pada tiga varietas bawang merah dapat dilihat pada Tabel 3.

Tabel 2. Rata-rata jumlah anakan akibat pemotongan umbi bibit pada tiga varietas bawang merah pada pada umur 14, 21, 28, 35, 42, 49 dan 56 hari setelah tanam.

\begin{tabular}{|c|c|c|c|c|c|c|}
\hline \multirow{2}{*}{ Umur } & \multirow{2}{*}{ Varietas $(\mathrm{V})$} & \multicolumn{4}{|c|}{ Pemotongan Umbi bibit (P) } & \multirow{2}{*}{ Rata-rata } \\
\hline & & $\mathrm{P}_{0}$ & $\mathrm{P}_{1}$ & $\mathrm{P}_{2}$ & $\mathrm{P}_{3}$ & \\
\hline \multirow{3}{*}{$14 \mathrm{hst}$} & $\mathrm{V}_{1}$ & 4.33 & 4.61 & 4.44 & 5.11 & $4.63 \mathrm{a}$ \\
\hline & $\mathrm{V}_{2}$ & 3.83 & 5.56 & 4.94 & 4.50 & $4.71 \mathrm{a}$ \\
\hline & $\mathrm{V}_{3}$ & 5.72 & 6.89 & 6.56 & 6.17 & $6.33 \mathrm{~b}$ \\
\hline \multicolumn{2}{|c|}{ Rata-rata } & 4.63 & 5.69 & 5.31 & 5.26 & \\
\hline \multirow{3}{*}{$21 \mathrm{hst}$} & $\mathrm{V}_{1}$ & 5.06 & 5.28 & 4.56 & 5.83 & $5.18 \mathrm{a}$ \\
\hline & $\mathrm{V}_{2}$ & 5.00 & 5.89 & 5.61 & 5.56 & $5.51 \mathrm{a}$ \\
\hline & $\mathrm{V}_{3}$ & 6.39 & 8.33 & 7.89 & 7.56 & $7.54 \mathrm{~b}$ \\
\hline
\end{tabular}




\begin{tabular}{|c|c|c|c|c|c|c|}
\hline \multirow{2}{*}{ Umur } & \multirow{2}{*}{ Varietas $(\mathrm{V})$} & \multicolumn{4}{|c|}{ Pemotongan Umbi bibit (P) } & \multirow{2}{*}{ Rata-rata } \\
\hline & & $\mathrm{P}_{0}$ & $\mathrm{P}_{1}$ & $\mathrm{P}_{2}$ & $\mathrm{P}_{3}$ & \\
\hline \multicolumn{2}{|c|}{ Rata-rata } & 5.48 & 6.50 & 6.02 & 6.31 & \\
\hline \multirow{3}{*}{28 hst } & $\mathrm{V}_{1}$ & 5.06 & 5.28 & 4.56 & 5.83 & $5.18 \mathrm{a}$ \\
\hline & $\mathrm{V}_{2}$ & 5.00 & 5.89 & 5.61 & 5.56 & $5.51 \mathrm{a}$ \\
\hline & $\mathrm{V}_{3}$ & 6.39 & 8.33 & 7.89 & 7.56 & $7.54 \mathrm{~b}$ \\
\hline \multicolumn{2}{|c|}{ Rata-rata } & 5.48 & 6.50 & 6.02 & 6.31 & \\
\hline \multirow{3}{*}{35 hst } & $\mathrm{V}_{1}$ & 5.44 & 5.67 & 5.33 & 6.22 & $5.67 \mathrm{a}$ \\
\hline & $\mathrm{V}_{2}$ & 6.67 & 7.17 & 7.50 & 6.89 & $7.06 \mathrm{a}$ \\
\hline & $\mathrm{V}_{3}$ & 8.50 & 9.33 & 10.61 & 8.72 & $9.29 \mathrm{~b}$ \\
\hline \multicolumn{2}{|c|}{ Rata-rata } & 6.87 & 7.39 & 7.81 & 7.28 & \\
\hline \multirow{3}{*}{42 hst } & $\mathrm{V}_{1}$ & 5.50 & 7.89 & 5.39 & 6.78 & $6.39 \mathrm{a}$ \\
\hline & $\mathrm{V}_{2}$ & 6.56 & 7.94 & 7.89 & 7.11 & $7.38 \mathrm{a}$ \\
\hline & $\mathrm{V}_{3}$ & 8.67 & 9.28 & 10.33 & 8.83 & $9.28 \mathrm{~b}$ \\
\hline \multicolumn{2}{|c|}{ Rata-rata } & 6.91 & 8.37 & 7.87 & 7.57 & \\
\hline \multirow{3}{*}{49 hst } & $\mathrm{V}_{1}$ & 5.50 & 7.89 & 5.39 & 6.78 & $6.39 \mathrm{a}$ \\
\hline & $\mathrm{V}_{2}$ & 6.56 & 7.94 & 7.89 & 7.11 & $7.38 \mathrm{a}$ \\
\hline & $\mathrm{V}_{3}$ & 8.67 & 9.28 & 10.33 & 8.83 & $9.28 \mathrm{~b}$ \\
\hline \multicolumn{2}{|c|}{ Rata-rata } & 6.91 & 8.37 & 7.87 & 7.57 & \\
\hline \multirow{4}{*}{56 hst } & $\mathrm{V}_{1}$ & 5.50 & 7.89 & 5.39 & 6.78 & $6.39 \mathrm{a}$ \\
\hline & $\mathrm{V}_{2}$ & 6.56 & 7.94 & 7.89 & 7.11 & $7.38 \mathrm{a}$ \\
\hline & $\mathrm{V}_{3}$ & 8.67 & 9.28 & 10.33 & 8.83 & $9.28 \mathrm{~b}$ \\
\hline & rata & 6.91 & 8.37 & 7.87 & 7.57 & \\
\hline
\end{tabular}

Keterangan: Angka yang diikuti oleh huruf yang sama pada kolom, baris dan umur yang sama tidak menunjukkan berbeda nyata menurut uju BNJ $5 \%$.

Tabel 3. Rata-rata jumlah umbi tanaman bawang merah akibat penggunaan tiga varietas bawang merah terhadap beberapa tingkat pemotongan umbi bibit (saat panen).

\begin{tabular}{cllrlll}
\hline \multirow{2}{*}{ Varietas $(\mathrm{V})$} & \multicolumn{5}{c}{ Pemotongan umbi bibit $(\mathrm{P})$} & \multirow{2}{*}{ Rata-rata } \\
\cline { 2 - 5 } & $\mathrm{P}_{0}$ & $\mathrm{P}_{1}$ & $\mathrm{P}_{2}$ & $\mathrm{P}_{3}$ & \\
\hline $\mathrm{V}_{1}$ & 5.67 & 6.83 & 5.56 & 6.94 & $6.25 \mathrm{a}$ \\
$\mathrm{V}_{2}$ & 6.72 & 8.11 & 8.06 & 7.28 & $7.54 \mathrm{a}$ \\
$\mathrm{V}_{3}$ & 8.83 & 9.44 & 10.50 & 9.00 & $9.44 \mathrm{~b}$ \\
\hline Rata-rata & 7.07 & 8.13 & 8.04 & 7.74 & \\
\hline
\end{tabular}

Keterangan: Angka yang diikuti oleh huruf yang sama pada kolom untuk perlakuan yang berbeda, tidak menunjukkan berbeda nyata menurut uju BNJ 5\%.

Berdasarkan Tabel 3 menunjukkan bahwa penggunaan tiga varietas bawang merah berbeda nyata terhadap jumlah umbi dimana pengamatan varietas bawang merah $\mathrm{V}_{3}$ (Varietas Tajuk) memiliki jumlah umbi terbanyak dengan rata-rata 9,44 dibandingkan penggunaan varietas $V_{1}$ (varietas Bauji) dan $V_{2}$ (Varietas Bima).

Penggunaan bibit bawang merah dengan Varietas Tajuk berpengaruh nyata pada peningkatan jumlah umbi dibandingkan varietas lainnya. Hal ini karena varietas Tajuk memiliki daun yang lebih besar dan tebal sehingga mampu menyimpan air lebih, maka dari itu daya adaptasi varietas Tajuk terhadap cuaca dan tanah spodosol lebih tinggi. Daun yang besar lebih banyak menyerap sinar matahari sehingga dapat berfotosintensis dengan maksimal, sehingga ketersediaan energi untuk perkembangan pertumbuhan tanaman menjadi lebih baik. Hal ini sesuai dengan pernyataan Nugraha (2014) yaitu fungsi daun sebagai organ utama tempat fotosintesis berlangsung, semakin besar luas daun yang dimiliki tanaman, semakin tinggi pula tingkat penangkapan sinar matahari dan fiksasi CO2. Sehingga mempengaruhi hasil asimilat pada umbi. Hal lain juga disebabkan karena lingkungan dan setiap varietas memberikan hasil yang berbeda dengan varietas yang lain. Menurut Surajudin (2015), ada beberapa hal yang menyebabkan tanaman bawang merah produksinya rendah 
yaitu macam kultivar/varietas, bibit yang kurang baik, cara tanam dan pemupukan yang kurang tepat. Penjelasan ini juga sesuai dengan penelitian Ambarwati dan Yudono (2003) bahwa varietas yang berdaya hasil tinggi di satu tempat belum tentu memberikan hasil yang tinggi di tempat lain. Allard (2005) juga menambahkan gen-gen dari tanaman tidak akan dapat menyebabkan perkembangan suatu karakter terkecuali apabila gen-gen tersebut berada dalam lingkungan yang sesuai dan sebaliknya tidak akan ada pengaruh gen-gen terhadap perkembangan karakteristik dan merubah tingkat keadaan lingkungan terkecuali gen yang diperlukan ada.

\section{Bobot Brangkasan Segar}

Hasil analisis ragam menunjukkan bahwa interaksi pemotongan umbi dan penggunaan tiga varietas bawang merah berpengaruh nyata terhadap bobot brangkasan segar.. Rata-rata bobot brangkasan segar akibat pemotongan umbi bibit pada tiga varietas bawang merah dapat dilihat pada Tabel 4.

Berdasarkan Tabel 4 penggunaan varietas tajuk dengan pemotongan umbi bibit $1 / 3$ $\left(\mathrm{V}_{3} \mathrm{P}_{2}\right)$ merupakan kombinasi perlakuan terbaik pada bobot berangkasan segar dengan rata-rata $1126,67 \mathrm{~g}$ dan berbeda nyata dengan perlakuan lainnya, hal ini diduga pada pemotongan umbi bibit $1 / 3$ bagian tanaman bawang merah akan memacu pertumbuhan bawang merah sehingga menghasilkan bobot basah umbi. Hal ini sesuai dengan pendapat Soedomo (1992) yang menyatakan perlakuan pemotongan umbi bibit sangat berpengaruh terhadap persentase berat umbi yang dihasilkan. Ditambahkan oleh Sutapraja (1996), ada beberapa hal yang menyebabkan tanaman bawang merah produksinya rendah yaitu macam kultivar/varietas, bibit yang kurang baik, cara tanam dan pemupukan yang kurang tepat. Selain itu yang menyebabkan hasilnya lebih rendah karena pada saat kegiatan penelitian dominan hujan, dimana curah hujan menurut BMKG kota Palangka Raya (2018) pada bulan Mei, cuaca kota Palangka Rata kecamatan bukit batu sebesar 12 hari hujan dengan curah hujan
160,6 mm dengan lama penyinaran 172,2 jam dan suhu rata-rata $28,2^{\circ}$ menyebabkan rendahnya suhu tanah yang berpengaruh terhadap kelembaban tanah meningkat sehingga menyebabkan timbulnya penyakit seperti alternaria porri yang berakibat pada busuknya umbi yang menyebabkan kehilangan produksi. Hal ini sesuai dengan pernyataan Rahayu dan Berlian (1999) yang menyatakan bahwa tanaman bawang merah tidak tahan terhadap tempat yang tergenang air. Banyaknya air di musim hujan dapat menyebabkan timbulnya penyakit yang disebabkan oleh cendawan. Purbiati (2010) juga mengatakan penyakit yang sangat penting pada bawang merah adalah Alternaria , pada tingkat serangan berat menimbulkan kehilangan hasil atau kerusakan tanaman sekitar 30-40\%.

Kombinasi pemotongan umbi bibit bawang merah $1 / 3$ bagian dan penggunaan varietas tajuk mampu meningkatkan bobot brangkasan segar dengan hasil rata-rata 1126,67 $\mathrm{g} /$ petak dengan luas panen $0,48 \mathrm{~m}^{2}$ atau setara 23,47 ton.ha ${ }^{-1}$.

\section{Bobot Brangkasan Kering}

Hasil analisis ragam interaksi serta faktor tunggal varietas dan pemotongan umbi bibit tidak berpengaruh nyata terhadap bobot brangkasan kering. Rata-rata bobot brangkasan kering akibat pemotongan umbi bibit pada tiga varietas bawang merah pada saat dikering anginkan dapat dilihat pada Tabel 5.

Dari Tabel 5 dapat dilihat bahwa pemotongan umbi bibit $1 / 3$ dan penggunaan varietas tajuk menunjukkan bobot brangkasan kering terbaik, hal ini terjadi karena Varietas Tajuk memiliki diameter daun yang cukup luas sehingga mampu mendukung tanaman berfotosintesis dengan baik. Pernyataan ini sesuai dengan Azmi et. al. (2011) banyaknya cahaya yang diterima daun selama masa pengumbian dapat meningkatkan padatan terlarut pada umbi, sehingga memnghasilkan bobot umbi simpan yang tinggi. Hal ini ini juga terjadi karena adanya respirasi dari penjemuran atau pengeringan bawang merah. 
Tabel 4. Rata-rata bobot brangkasan segar bawang merah penggunaan tiga varietas bawang merah terhadap beberapa tingkat pemotongan umbi bibit.

\begin{tabular}{ccccccc}
\hline \multirow{2}{*}{ Varietas (V) } & \multicolumn{5}{c}{ Pemotongan umbi bibit $(\mathrm{P})$} & \multirow{2}{*}{ Rata-rata } \\
\cline { 2 - 5 } & $\mathrm{P}_{0}$ & $\mathrm{P}_{1}$ & \multicolumn{1}{c}{$\mathrm{P}_{2}$} & $\mathrm{P}_{3}$ & \\
\hline $\mathrm{V}_{1}$ & $810.00 \mathrm{ab}$ & $796.67 \mathrm{ab}$ & $775.00 \mathrm{ab}$ & $590.00 \mathrm{a}$ & 742.92 \\
$\mathrm{~V}_{2}$ & $676.67 \mathrm{ab}$ & $801.67 \mathrm{ab}$ & $748.33 \mathrm{ab}$ & $903.33 \mathrm{ab}$ & 782.50 \\
$\mathrm{~V}_{3}$ & $720.00 \mathrm{ab}$ & $1023.33 \mathrm{ab}$ & $1126.67 \mathrm{~b}$ & $514.44 \mathrm{a}$ & 846.11 \\
\hline Rata-rata & 735.56 & 873.89 & 883.33 & 669.26 & \\
\hline
\end{tabular}

Keterangan: Angka yang diikuti oleh huruf yang sama untuk perlakuan yang berbeda, tidak menunjukkan berbeda nyata menurut uji BNJ 5\%.

Tabel 5. Rata-rata bobot brangkasan kering akibat pemotongan umbi bibit pada tiga varietas bawang merah

\begin{tabular}{cccccc}
\hline \multirow{2}{*}{ Varietas $(\mathrm{V})$} & \multicolumn{4}{c}{ Pemotongan umbi bibit (P) } & \multirow{2}{*}{ Rata-rata } \\
\cline { 2 - 5 } & $\mathrm{P}_{0}$ & $\mathrm{P}_{1}$ & $\mathrm{P}_{2}$ & $\mathrm{P}_{3}$ & \\
\hline $\mathrm{V}_{1}$ & 471.67 & 431.67 & 440.00 & 396.67 & 435.00 \\
$\mathrm{~V}_{2}$ & 430.00 & 496.67 & 478.33 & 578.33 & 495.83 \\
$\mathrm{~V}_{3}$ & 463.33 & 666.67 & 716.67 & 365.00 & 552.92 \\
\hline Rata-rata & 455.00 & 531.67 & 545.00 & 446.67 & \\
\hline
\end{tabular}

Keterangan: Angka yang diikuti oleh huruf yang sama pada perlakuan yang berbeda, tidak menunjukkan berbeda nyata menurut uju BNJ 5\%.

Menurut Gardner et. al.,(1991) berat kering merupakan keseimbangan antara fotosintesis dan respirasi. Fotosintesis mengakibatkan peningkatan berat kering tanaman karena pengambilan $\mathrm{CO}_{2}$ sedangkan respirasi mengakibatkan penurunan berat kering karena pengeluaran $\mathrm{CO}_{2}$. Produksi tanaman biasanya lebih akurat dinyatakan dengan ukuran bobot brangkasan kering daripada dengan berat basah, karena berat basah sangat dipengaruhi oleh kondisi kelembaban (Sitompul dan Guritno, 1995)

Faktor suhu juga memengaruhi hasil berat kering brangkasan pada setiap varietas tanaman bawang merah, dimana saat tanaman bawang merah membentuk umbi pada bulan Mei, cuaca kota Palangka Rata kecamatan bukit batu sebesar 12 hari hujan dengan curah hujan 160,6 mm dengan lama penyinaran 172,2 jam dan suhu rata-rata $28,2^{\circ}$ (BMKG Palangka Raya, 2018). Hal ini mengakibatkan cahaya yang diterima daun pada saat pengumbian tidak maksimal. Pernyataan ini sesuai dengan pendapat Hidayat (2004) bahwa banyaknya cahaya yang diterima daun selama masa pengumbian dapat meningkatkan padatan terlarut dalam umbi bawang merah, makin tinggi padatan terlarut dalam umbi makin rendah susut bobotnya, tetapi secara visual umbi bawang merah yang dihasilkan memiliki ukuran umbi yang besar, hal ini diduga karena adanya pemberian pupuk NPK. Serapan hara sangat menentukan bobot kering tanaman dan kadar hara (Asandhi et. al., 2005).

Rata-rata hasil bobot brangkasan kering pemotongan umbi bibit $1 / 3$ bagian didapat sebesar $545 \mathrm{~g}$ dengan luas panen $0,48 \mathrm{~m}^{2}$ atau sama dengan 11,35 ton.ha ${ }^{-1}$. Hal ini disebabkan pada pemotongan $1 / 3$ bagian umbi menyisakan bagian besar umbi untuk ditanam. Artinya, cadangan makanan pada pemotongan umbi bibit $1 / 3$ bagian tersebut terdapat karbohidrat yang digunakan untuk menghasilkan jumlah anakan.

Varietas tajuk memiliki hasil bobot brangkasan kering yang paling tinggi dibanding varietas Bauji dan Bima, dengan rata-rata hasil panen bobot brangkasan kering sebesar 552,92 $\mathrm{g}$ atau setara dengan 11,52 ton.ha $^{-1}$. Hal ini juga sesuai dengan deskripsi tanaman bawang merah varietas Tajuk dengan potensi jumlah umbi 5-15 per rumpun, berat umbi 30-80 g per rumpun dan juga varietas tajuk mampu beradaptasi dengan baik pada 
musim kemarau dan tahan terhadap musim hujan. Tingginya produksi bawang merah varietas tajuk sejalan dengan variabel pertumbuhan yang diamati, pada tinggi tanaman umur 49 hari mencapai rata-rata 34,95 , begitu juga dengan jumlah daun pada umur 49 hari mencapai 31,12 dan rata-rata jumlah anakan yang didapat sebanyak 9,28 dan sebanding dengan jumlah umbi yang dihasilkan dengan rata-rata 9,44. Hasil panen pada penelitian ini hampir mencapai karakteristik dari deskripsi hasil umbi per hektar tanaman bawang merah varietas tajuk yang berasal dari pulau jawa yang mencapai 12-16 ton.ha ${ }^{-1}$.

\section{KESIMPULAN}

Kombinasi perlakuan pemotongan umbi 1/3 dan penggunaan varietas tajuk mampu meningkatkan jumlah daun dan hasil bobot brangkasan segar. Hasil bawang merah per petak panen terbaik terdapat pada perlakuan pemotongan umbi $1 / 3$ (sepertiga) dan penggunaan varietas tajuk dengan perolehan hasl bobot berangkasan segar 1126,67 g/petak panen atau setara dengan 23,47 ton.ha ${ }^{-1}$.

\section{Saran}

Berdasarkan hasil penelitian disarankan sebaiknya petani bawang merah menggunakan varietas Tajuk dengan melakukan pemotongan umbi bibit $1 / 3$ bagian. Varietas Tajuk mempunyai daya adaptasi tinggi dan relatif tahan terhadap serangan penyakit Fusarium oxysporum dan Alternaria porri.

\section{DAFTAR PUSTAKA}

Allard, R. W., 2005. Principles of Plant Breeding. John Wiley and Sons. New York.

Ambarwati, E. dan P. Yudono. 2003. Keragaan Stabilitas Hasil Bawang Merah. Ilmu. 10(2):1-10.

Asandhi, A.A., Nurtika, N. dan N. Sumarni. 2005. Optimasi Pupuk dalam Usahatani LEISA Bawang Merah di Dataran Rendah. Lembang, Bandung.

Azmi C. IM Hidayat. G Wiguna. 2011. Pengaruh varietas dan ukuran umbi terhadap produktiftitas bawang merah. Hort. 21 (3):206-213.
Badan Pusat Statistik. 2017. Kota Palangka Raya dalam Angka. BPS Kota Palangka Raya.

Badan Pusat Statistik. 2017. Statistik Indonesia 2017. Badan Pusat Statistik Indonesia.

Firmansyah, 2014. Uji Adaptasi Bawang Merah di Lahan Gambut Pada Saat Musim Hujan di Kalimantan Tengah. J. Hort. 24(2):122-123, 2014. Diterbitkan tanggal 30 Mei 2014.

Gardner, F. R.,R.B. Pearce, dan R.L. Mitchell. 1991. Fisiologi Tanaman Budidaya. Tropik. Terjemahan Herawati Susilo. UI Press.. Jakarta.

Hidayat, 2004, Budidaya Bawang Merah, Beberapa Penelitian di Kabupaten Brebes, Direktorat Tanaman Sayuran Dan Biofarmatika, Brebesn.

Kimbal, J.W. 1990. Biologi. Edisi Kelima. Diterjemahkan Siti Soetarni, Tjitrosomo, dan Sagimin. Erlangga. Jakarta.

Nugraha W.M., T. Sumarni., dan A. Suryanto. 2014. Penggunaan Ajir dan Mulsa untuk meningkatkan produksi kentang (Solanum tubrtosum.L) Varietas Granola. Jurusan budidaya pertanian. Fakultas Pertanian. Universitas Brawijaya.

Purbiati, T. 2015. Pengkajian Adaptasi Varietas Bawang Merah Toleran Hama Penyakit pada Lahan Kering di Kalimantan Barat. BPTP-Kalimantan Barat: 4-8.

Pitojo, Setijo. 2003. Benih Bawang Merah. Penerbit : Kanisius. Yogyakarta

Putra, R.Y., Haryati, H. Dan L.Mawarni. 2012. Respon Pertumbuhan dan HasilBawang Sabrang (Eleutherine americana Merr.) pada Bebrapa JarakTanam dan Berbagai TingkatPemotongan Umbi Bibit. Jurnal onlineAgroekoteknologi Vol.1. No.1,Desember 2012.

Putrasamedja, S., (2010), "Adaptasi Klon Klon Bawang Merah (Allium ascalonikum L.) di Pabedebilan Losari, Cirebon". Agritech. 12 (2) : 81-88.

Rahayu, E dan N. Berlian. 2004. Bawang Merah. Penebar Swadaya, Jakarta.(http://id.portalgaruda.org/ind 
ex.php?ref=browse \&mod=viewarticl e\&article $=1$ Jakarta 11184 (Diakses 13 januari 2018).

Rukmana, R, 1995. Bawang merah Budidaya Dan Pengolahan Pasca panen. Kanisius. Jakarta

Salisbury, F.B. \& Ross, C.W. 1995. Fisiologi Tumbuhan.. Jilid III. Terjemahan dari Plant Physiology. ITB. Bandung.

Samadi, b dan b, Cahyono. 2005. Identifikasi Budidaya Bawang Merah. Kanisius. Yogyakarta.74hlm(http://id.portalgar uda.org/index.php?ref=browse\&mod $=\quad$ viewarticle\&article $=111184$ ) (Diakses pada 13 Januari 2018).

Simatupang, S. 1997. Sifat dan Ciriciri Tanah. Institut Pertanian Bogor. Bogor. 86 hlm.
Soedomo, R. P., 1992. Pengaruh pemotongan ujung umbi dan lama penyimpanan umbi bibit bawang merah (Allium ascalonicum L) terhadap hasil umbi di Brebes, Jawa Tengah.

Surajudin As'ad., R. Yusuf, dan H. Mas'ud. 2015. Respon Tanaman Bawang Merah (Allium ascalonicum L.) Varietas Lembah Palu Terhadap Pemberian Jenis Mulsa Dan Pupuk Organik Cair.

Sutapradja, H. 1996. Kaitan antara cara pemberian $\mathrm{Cu}$ dan dosis $\mathrm{K}, \mathrm{Mg}$ serta Ca terhadap pertumbuhan dan hasil bawang merah. J. Hort. 5(5): 17-22..

Wibowo, S. 2005. Budidaya Bawang Putih, Bawang Merah dan Bawang Bombay. Penebar Swadaya. Jakarta.201 hlm. Pupuk Kalium dan Jarak Tanam. Jurnal Skripsi. Unuversitas Sumatera Utara. Medan. 